Article

\title{
Assessment of PCBs in Surface Waters at Ultratrace Levels: Traditional Approaches and Biomonitoring (Lake Baikal, Russia)
}

\author{
Alexander G. Gorshkov*(D), Olga V. Kustova (D) and Yurij S. Bukin (D) \\ Limnological Institute, Siberian Branch of the Russian Academy of Sciences, Ulan-Batorskaya St. 3, \\ 664033 Irkutsk, Russia; delete_21@mail.ru (O.V.K.); bukinyura@mail.ru (Y.S.B.) \\ * Correspondence: gorchkov_ag@mail.ru
}

check for updates

Citation: Gorshkov, A.G.; Kustova, O.V.; Bukin, Y.S. Assessment of PCBs in Surface Waters at Ultratrace Levels: Traditional Approaches and Biomonitoring (Lake Baikal, Russia). Appl. Sci. 2022, 12, 2145. https:// doi.org/10.3390/app12042145

Academic Editor: Elida Nora Ferri

Received: 24 January 2022

Accepted: 14 February 2022

Published: 18 February 2022

Publisher's Note: MDPI stays neutral with regard to jurisdictional claims in published maps and institutional affiliations.

Copyright: (c) 2022 by the authors. Licensee MDPI, Basel, Switzerland. This article is an open access article distributed under the terms and conditions of the Creative Commons Attribution (CC BY) license (https:/ / creativecommons.org/licenses/by/ $4.0 /)$.

\begin{abstract}
This article presents the results of the assessment of PCB concentrations in surface waters at ultratrace level of concentrations. The assessment of PCB concentrations is based on data from monitoring PCBs in Baikal water within the conventional approach as well as from biomonitoring of PCBs using Baikal omul, Coregonus migratorius, Georgi, 1775 (C. migratorius), as a bioindicator. The time cycle of the monitoring covered the period from 2014 to 2021 . The concentrations of PCBs in the water were estimated from the concentrations of seven indicator congeners: $28,52,101,118,138,153$, and 180, and from congeners of dioxin-like (dl) PCBs in the tissues of C. migratorius. The average value and the statistically significant range of the detected total concentrations $\left(\Sigma_{7} \mathrm{PCBs}\right)$ in Baikal water were 0.30 and $0.26-0.34 \mathrm{ng} / \mathrm{L}$, respectively. In the tissues of $C$. migratorius, the average value and the range of $\Sigma_{7} \mathrm{PCB}$ concentrations were 5.6 and $4.9-6.3 \mathrm{ng} / \mathrm{g}(\mathrm{ww})$, respectively, and for dl-PCBs, 1.5 and $1.3-1.7 \mathrm{ng} / \mathrm{g}(\mathrm{ww})$, respectively. The total toxicity equivalent of the detected dl-PCBs was in the WHO-TEQ ${ }_{(2005)}$ range from 0.03 to $0.06 \mathrm{pg} / \mathrm{g}(\mathrm{ww})$. The concentrations of $\Sigma_{7} \mathrm{PCBs}$ in Baikal water and dl-PCBs in the tissues of $C$. migratorius corresponded to the concentration levels in the European alpine lakes and the tissues of $S$. trutta fish inhabiting these lakes.
\end{abstract}

Keywords: PCBs; monitoring; biomonitoring; statistical analysis; Lake Baikal

\section{Introduction}

Accumulation of persistent organic pollutants (POPs) in surface waters is the most important problem of the international community within the framework of its Sustainable Development Goal. The development of reliable methods for monitoring and assessing the concentrations of POPs at the background level of concentrations is one of the tasks, the solution of which requires priority measures [1,2]. Among POPs, polychlorinated biphenyls (PCBs) stand out for their exceptional chemical and biological stability and global distribution: pollutants of this class are found in air, water, soil, and biota. PCBs have many unique physical and chemical properties that have determined their widespread application in various fields of technology. The total world production of PCBs is 1.5 million tons, of which approximately $10 \%$ remain in the environment [3-6]. When their toxic effect on living organisms was determined in extremely low doses, together with the ability to accumulate in biological objects, the Stockholm Convention prohibited the production and use of PCBs. They were included in the list of POPs and the OSPAR Convention included them in the list of priority pollutants $[7,8]$.

In the surface water of background areas, $\mathrm{PCBs}$ are present at ultratrace concentration levels. For example, in the Arctic water, PCBs were detected in the concentration range from 1.3 to $21 \mathrm{pg} / \mathrm{L}[9,10]$. It should be noted that data on the concentrations of PCBs in the water is scarce. Methodological problems may complicate the detection of PCBs at trace levels of concentrations, in particular, due to hydrophobicity of PCBs, i.e., sorption on the surface of suspended particles in the water column and accumulation in biota 
lipids. Increasing the volume of water samples up to $100 \mathrm{~L}$ or more [11,12] to reduce the lower limit of the range of detected PCB concentrations increases expended time and resources. A decrease in the number of samples (during the multiple high-volume sampling) increases the likelihood of missing local areas with high concentrations of PCBs. Otherwise, estimation based on the extreme short-term periods of water pollution in individual areas is possible. Passive sampling techniques [13] can estimate the concentrations of dissolved PCBs, but the assessment of the total concentration of PCBs in two phases of water matrix (aqueous solution and solid phase) as a biota habitat is more significant at the background level of pollution. In turn, the detection of PCBs at trace levels of concentration with the required reliability and accuracy is possible using modern gas chromatography-mass spectrometry techniques that provide high sensitivity and specificity $[14,15]$.

Biological monitoring, a determination of pollutants in aquatic bioindicator organisms directly exposed to these substances, is an alternative method to control POPs in surface water. Bioindicators must have certain relevant characteristics, in particular, accumulate PCBs in the amounts sufficient for their detection; their habitat must correspond to the boundaries of the studied water body, and it is possible to collect a sufficient number of specimens of these organisms [16]. Fish is the most widespread bioindicator of PCBs in water bodies; PCBs reflecting water pollution have been detected over a wide range of concentrations for both marine and freshwater species [17-27]. The dependence of the levels of PCB accumulation in fish on the concentrations of these substances in the water was used to assess temporal and spatial variations in surface waters, investigate vertical transport of pollutants from the surface to deep water layers $[19,28,29]$, and estimate the content of pollutants at the background level of concentrations [30-34].

When the industrial production of PCBs was ceased, their concentrations in fish, bottom sediments, and the atmosphere of the Arctic regions decreased [35-37]. At the present stage, the sources of PCBs include dismantling and disposal of equipment containing these substances as a structural material as well as various chemical and thermal processes, during which PCBs are formed as byproducts from landfills, waste disposal sites, or illegal stockpiles [38-41]. As shown in [3,42], the number of PCBs in the environment is currently not decreasing but even increasing in some regions of the world. For instance, as the climate warms, many POPs accumulated in the Arctic environment re-enter the atmosphere as a result of sea ice retreat and temperature rise [43].

We chose Lake Baikal as a model for estimating PCBs in surface water at ultratrace levels of concentration. Lake Baikal covers an area of $31,700 \mathrm{~km}^{2}$ and contains up to $20 \%$ of the world reserves of surface freshwater, $\sim 23,000 \mathrm{~km}^{3}$. Water in the lake is clean and has a low mineralization degree, and a minimal content of suspended organic matter and POPs [44-47]. The presence of PCBs in the aquatic ecosystem of Lake Baikal was first reported in [48]. At that time, the level of their concentrations in the water corresponded to the world background level [11,49-51]. According to independent studies, there was up to a 4.5-fold increase in the PCB concentrations in 2014 and 2015 [11,52] compared to the levels recorded in 1992 and 1993.

The increase in the PCB concentrations in Baikal water is of special concern because the lake is the most important water resource on the planet. This has highlighted the scientific problem of PCB control in the ecosystem of Lake Baikal, which is associated with the detection of PCBs in the surface water at the ultratrace level of concentrations. This study evaluates the results of PCB monitoring, which were obtained during the observation period from 2014 to 2021 at Lake Baikal. Monitoring of PCBs was carried out within the framework of the conventional approach, including water sampling according to a standardised procedure followed by the determination of the required pollutants in them by the GC-MS/MS method, as well as within the framework of biomonitoring using Baikal omul, Coregonus migratorius, Georgi, 1775 (C. migratorius), as a bioindicator. To identify the relationship between the concentrations of indicator PCB congeners and their total concentrations in the water and C. migratorius, key factors influencing the concentrations of $\mathrm{PCBs}$ in the water and bioindicator, we also carried out a comparative statistical analysis. 


\section{Materials and Methods}

\subsection{Sampling}

Water samples from the pelagic zone of Lake Baikal were collected by using an SBE-32 cassette sampler (Carousel Water Sampler, Sea-Bird Electronics, Bellevue, WA, USA) at 21 stations (Figure 1) in May 2015, May and September 2016, May 2018, May and September 2019, and June and September 2020 and 2021 (Table S1, supplementary materials). At each station, two samples were taken in $1 \mathrm{~L}$ glass bottles, to which $0.5 \mathrm{~mL}$ of a $1 \mathrm{M}$ aqueous solution of sodium azide (Merck, Darmstadt, Germany) was added as a preserving agent. Water bottles were closed using a lid with an aluminium foil gasket and stored at $5{ }^{\circ} \mathrm{C}$ until laboratory analysis.

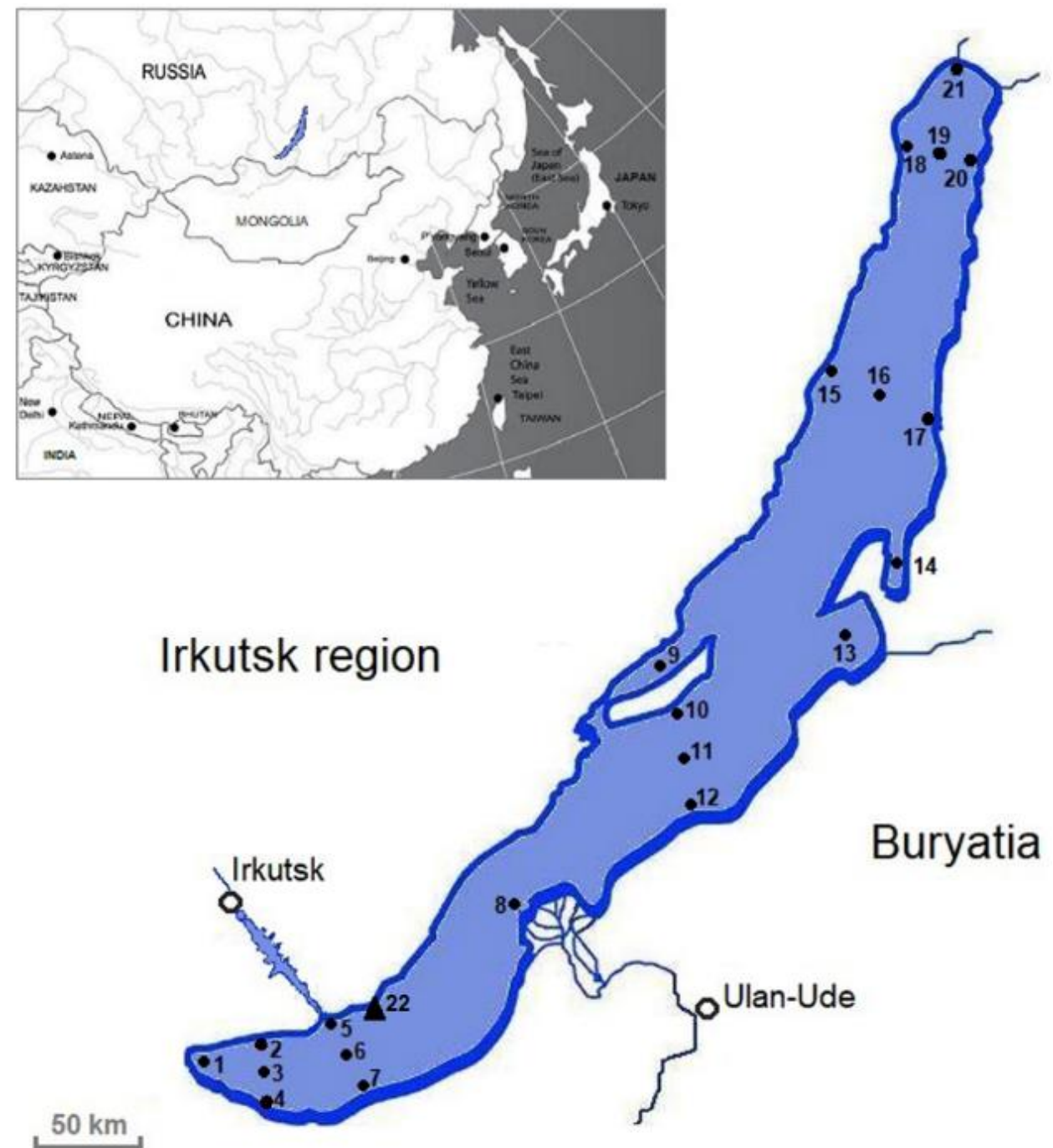

Figure 1. Map of Lake Baikal and sampling sites. At stations 1, 2, 4, 5, 7, 10, 12, 17, 18, 20, and 21, sampling was carried out from the upper water layer $(5 \mathrm{~m})$ at a distance of up to $3 \mathrm{~km}$ from the coast; at station 3, 6, 8, 11, 16, and 19 at reference central stations; at station 6-from the water column at depths of 5 to $1200 \mathrm{~m}$; at station 11-from the water column at depths of 5 to $1600 \mathrm{~m}$; at station 16 - from the water column at depths of 5 to $800 \mathrm{~m}$; and at station 22, C. migratorius was caught.

Baikal omul, Coregonus migratorius, Georgi, 1775 (C. migratorius), is fish species meeting the criteria for biological objects to be selected as bioindicators [16]: (i) C. migratorius migrates throughout the entire water area of Lake Baikal in a depth range up to $350 \mathrm{~m}$, including the zones of river runoff; (ii) it is a commercial fish species, ensuring economic efficiency of the sampling stage during monitoring; (iii) individuals at the age of three to seven years accumulate PCBs in an amount sufficient for their measurement with the 
required accuracy $[53,54]$. Coregonus migratorius was caught near station 22 (Figure 1) in March to July 2014, February 2016, March 2018-2020, and September 2017-2018. Collected fish were packed in aluminium foil, frozen, and stored at a temperature of $\leq$ minus $18-20{ }^{\circ} \mathrm{C}$. Identification characteristics of the selected Baikal omul (sex and age, Table S2) were determined according to the methods in $[55,56]$. The group of fish selected as bioindicators of PCBs included C. migratorius aged from three to seven years. The choice of this species of Baikal fish as bioindicators ensured the efficiency of the sampling because Baikal omul belongs to a commercial species.

The following reasons determined the choice of sampling seasons for water and $C$. migratorius. In the spring, after the ice melts, PCBs enter the lake water due to the melting of ice on the water surface of the lake and snow on its coast, in which PCBs have accumulated during the winter. Water samples collected in autumn reflect the accumulation of PCBs in water, which have come from the atmosphere in summer.

\subsection{Sample Processing}

In water samples and omul specimens, indicator congeners $28,52,101,118,138,153$, and 180, and dioxin-like congeners (dl-PCBs) 105, 114, 118, 123, and 126 (dl-PCBs 118 is one of the indicator congeners) were determined according to the technique shown in $[55,56]$ (Tables S3-S5). This technique included the following steps: extraction by n-hexane from $1 \mathrm{~L}$ of unfiltered water, the concentration of the extract to the volume of $\sim 0.1 \mathrm{~mL}$, and direct analysis of the extracts by GC-MS/MS. Before the determination of PCBs in C. migratorius, the fish selected for the analysis were thawed; the head, fins, and entrails of the fish were removed. The fish was then homogenised, discarding the skin, and large bones. PCBs were extracted from the mince via ultrasound extraction with a mixture of organic solvents: n-hexane/acetone (1:1). The extracts were purified with concentrated $\mathrm{H}_{2} \mathrm{SO}_{4}$.

\subsection{Instrumental Analysis}

Prepared extracts of the samples were analysed using an Agilent Technologies 7890B GC System 7000C GC-MS Triple Quad chromatography-mass spectrometer with an HT-8, SCE Analytical Science capillary column $(30 \mathrm{~m} \times 0.25 \mathrm{~mm} \times 0.25 \mu \mathrm{m})$. PCB peaks were recorded using the MRM mode and identified by relative retention times. PCB congeners were quantitated by the method of internal standards using a Marker-7 PCB Mixture ${ }^{13} \mathrm{C}$ (Cambridge Isotope Laboratories, Inc., Shirley, NY, USA) as a surrogate internal standard (Tables S3 and S4). The limits of determination (LOD) of PCB congeners in the water and fish were 0.01-0.02 $\mathrm{ng} / \mathrm{L}$ and $0.10-15 \mathrm{ng} / \mathrm{g}$ (ww), respectively. The LOD method was assessed based on the peak-to-peak signal-to-noise response of each of the PCB peaks (N/S) and at the lowest standard concentration. Values for $\mathrm{S} / \mathrm{N}>10$ were employed to determine the limit of quantitation (LOQ) for each target compound. Relative standard deviation $\left(\mathrm{RSD}_{\mathrm{Rl}}\right)$ for the determination procedure was 35\% for individual indicator congeners in the water: $28,52,101,118,138,153$, and 180; 25\% for individual indicator congeners and dl-PCBs in the fish: $28,52,101,105,114,118,123,126,138$, and 153; and $45 \%$ for congener 180 .

\subsection{Toxicity Assessment}

The dioxin toxicity equivalents (TEQ) for dl-PCBs were assessed as a product of the concentration of dl-PCB congeners $(C)$ and its corresponding toxicity equivalency factor (TEF) established by the International Program on Chemical Safety (IPCS) and World Health Organisation (WHO):

$$
\mathrm{TEQ}=\mathrm{C} \times \mathrm{TEF}
$$

where $\mathrm{C}(\mathrm{pg} / \mathrm{L})$ and $\mathrm{TEF}_{\mathrm{i}}$ are the concentrations and toxic equivalent factors (TEFs) of the dl-PCB congeners [57]. 


\subsection{Statistical Methods}

Confidence intervals for the mean values of the concentrations of $\mathrm{PCB}$ congeners and the total concentrations of seven indicator PCB congeners $\left(\Sigma_{7} \mathrm{PCBs}\right)$ were estimated using the bootstrap method in the «boot» package and the R programming language. Because of technical problems, a small part of the primary data on some PCB congeners for $C$. migratorius was unspecified. For further analysis, these missing data were replaced with averages for these congeners according to the recommendations [58].

PERMANOVA testing in the R package 'vegan' [59] was used for analysing an impact of the explanatory parameter: the year, month, the basin of Lake Baikal, and sampling depth for water, along with the year, month, age, and sex for C. migratorius (Tables S6 and S7). In the range of concentrations of the studied PCB congeners and $\Sigma_{7} \mathrm{PCBs}$ in the samples of Baikal water and C. migratorius, $p$ values of the PERMANOVA analysis were corrected for false discovery rate in multiple comparisons using the Benjamini-Hochberg equation [60].

To determine the similarity and difference between water samples and separately between the specimens of $C$. migratorius in the concentrations of various PCB congeners and $\Sigma_{7} \mathrm{PCBs}$, principal component analysis (PCA) was applied by using the «factoextra» package [61] for the R programming language. For analysis, data on water and C. migratorius were previously converted into 'integral samples', which were average values for the concentrations of $\mathrm{PCB}$ congeners over a set of explanatory parameters, indicating, according to the results of PERMANOVA analysis, a significant effect on PCB concentrations in the samples. Before PCA, all PCB concentrations were transformed to eliminate the physical dimensions by ranging from 0 to 1 .

Pairwise correlations between all concentrations of the studied PCB congeners and the total concentration of PCB in samples of Baikal water and Baikal omul (C. migratorius) were estimated with Spearman's $r$ correlation coefficient. Only reliable correlation coefficients $(p<0.05)$ were included in analysis. $p$ values for the correlation coefficients were calculated using Spearman's «W» statistics and corrected for false discovery rate in multiple comparisons using the Benjamini-Hochberg equation [60]. Unreliable values of correlation coefficients were replaced with 0 values. Pairwise correlations were visualized with a heat map generated using "gplots» [62] in R. Lines and columns in the correlation matrix were clustered and grouped in order of similarity (i.e., Euclidean distance metric and the complete-link clustering method).

To determine the relationship between the concentrations of the studied PCB congeners and $\Sigma_{7} \mathrm{PCBs}$ for the samples of Baikal water and C. migratorius averaged over the year of sampling, the Mantel test $[63,64]$ was used based on the Pearson correlation coefficient; the significance of the correlation was determined by the permutation test (10,000 permutations). Distance matrices for the Mantel test that determine the differences for concentration of PCB congeners between the water samples and between $C$. migratorius samples were calculated using the Euclidean metric. The Mantel test was performed using the R package 'vegan' [59].

Relative error statistics for repeated measurements of PCB concentrations for all samples from Lake Baikal were estimated as a relative difference between the maximum and minimum concentration of analytical repetitions of one measurement (relative error $=$ $100 \times(\max -\min ) / \max , \%)($ Tables S8 and S9).

All primary data are available in tables table_Sup_1.xlsx —water data, table_Sup_2.xlsxC. migratorius data in supplementary material.

\section{Results and Discussion}

\subsection{PCBs in the Upper Water Layer of the Pelagic Zone and Deep Layers of the Water Column of Lake Baikal}

The concentrations of PCBs in the water of Lake Baikal were characterised by seasonal and interannual variability (Figure 2). In May 2015, we detected the maximum total concentrations of PCB congeners ( $\sum$ PCBs) ranging from 1.4 to $6.6 \mathrm{ng} / \mathrm{L}$. There were 24 to 34 congeners of PCBs dominated by homologues of penta-dichlorobiphnyls as well as 7 indi- 
cator congeners $28,52,101,118,153,138$, and 180. The total concentrations of indicator PCB congeners ( $\sum_{7} \mathrm{PCBs}$ ) ranged from 0.43 to $2.0 \mathrm{ng} / \mathrm{L}$, and the contribution from $\sum_{7} \mathrm{PCBs}$ to the total concentration of all detected congeners ranged from 28 to 35\%. In September 2019, the concentration of $\sum_{7} \mathrm{PCBs}$ also increased at some stations (19 and 21$)$ to $0.24-2.8 \mathrm{ng} / \mathrm{L}$ with an increase in the number of the detected congeners to 27 . Indicator congeners were detected in the concentration range from 0.17 to $1.3 \mathrm{ng} / \mathrm{L}$ with a contribution to $\sum \mathrm{PCBs}$ of up to $40-70 \%$. The minimum concentrations of $\sum$ PCBs in Baikal water ranged from 0.11 to $0.82 \mathrm{ng} / \mathrm{L}$, and the number of the detected congeners were recorded in September 2016, May 2018 and 2019, and in the spring and summer of 2020 and 2021. The concentrations of $\sum_{7} \mathrm{PCBs}$ in these seasons ranged from $\leq 0.11$ to $0.47 \mathrm{ng} / \mathrm{L}$. The average concentration and statistically significant range of detected $\Sigma_{7} \mathrm{PCB}$ concentrations in Baikal water were 0.30 and $0.26-0.34 \mathrm{ng} / \mathrm{L}$, respectively. Notably, the indicated level of the detected $\sum \mathrm{PCB}$ concentrations was comparable with the concentrations of PCBs in Lake Baikal identified previously in 1992 and 1993 (0.08-1.9 ng/L) and estimated as background [49,51].

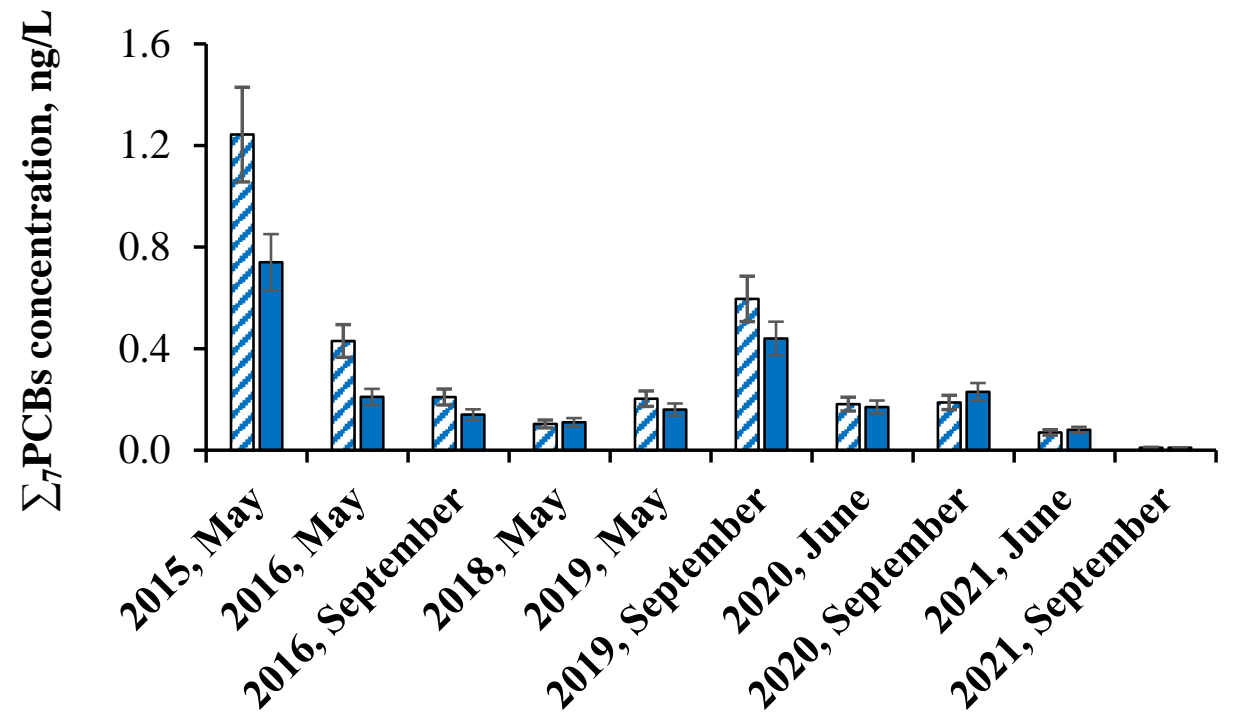

\section{Seasons}

Figure 2. Average concentrations of $\sum_{7} \mathrm{PCB}$ in the pelagic zone $\square$ and deep layers $\square$ of Lake Baikal determined during the monitoring of PCBs in Baikal water.

The global atmospheric transport is the dominant source of PCBs in Baikal water [11,49-51]. An increase in the concentrations of $\sum$ PCBs in May 2015 and September 2019 was likely due to the influx of PCBs from additional sources, which a change in the ratio of indicator congeners indicated. In spring 2015, the proportion of indicator congeners with a high degree of chlorination $(138,153$, and 180) increased in water samples up to $30-37 \%$. In autumn 2019, the proportion of pentachlorinated congeners 101 and 118 increased, and the proportion of 'light' tri- and tetrachlorinated congeners 28 and 52 decreased compared to the monitoring data during spring 2015. During the minimum concentrations of PCBs in the water of the pelagic zone of Lake Baikal, tri-, tetra-, and pentachlorinated homologues $(28,52,101$, and 118) predominated in the composition of indicator congeners, whose total concentrations reached $80-90 \%$ in the fraction of indicator PCBs.

Seasonal changes in the PCB concentrations in the upper water layer $(5 \mathrm{~m})$ of the pelagic zone in May 2015 and September 2019 were not tracked throughout the water column to depths of 800-1600 m (depending on the depth of the lake's basin). In May 2015, a high level of $\Sigma_{7} \mathrm{PCBs}$ in the upper water layer $(5 \mathrm{~m})$ of the southern basin of the lake, up to $3.1 \mathrm{ng} / \mathrm{L}$, was recorded at some stations. However, in deep water layers of the water column (50-1200 m), the $\Sigma_{7}$ PCB concentrations remained in a narrow range from 0.20 to 
$0.51 \mathrm{ng} / \mathrm{L}$. An increase in the $\Sigma_{7} \mathrm{PCB}$ concentrations in the upper water layer at stations 19 and 21 to $1.6-2.2 \mathrm{ng} / \mathrm{L}$ in autumn 2019 was also not accompanied by an increase in the $\Sigma_{7} \mathrm{PCB}$ concentrations at depths of 50 to $800 \mathrm{~m}$, which remained at a minimum level from 0.31 to $0.69 \mathrm{ng} / \mathrm{L}$.

\section{2. $P C B$ s in Coregonus migratorius}

We studied Baikal omul, C. migratorius, as a bioindicator of PCBs in Baikal water. In the course of biomonitoring, we collected and analysed 46 individuals of the C. migratorius population of Lake Baikal. The analysis revealed that the concentration of PCBs in fish specimens depends on the season and year of sampling (Figure 3). In the investigated specimens, we detected from 30 to 47 PCB congeners, including seven indicator congeners. The average concentrations and statistically significant range of the detected $\Sigma_{7} \mathrm{PCBs}$ in $\mathrm{C}$. migratorius were 5.6 and $4.9-6.3 \mathrm{ng} / \mathrm{g}(\mathrm{ww})$, respectively.

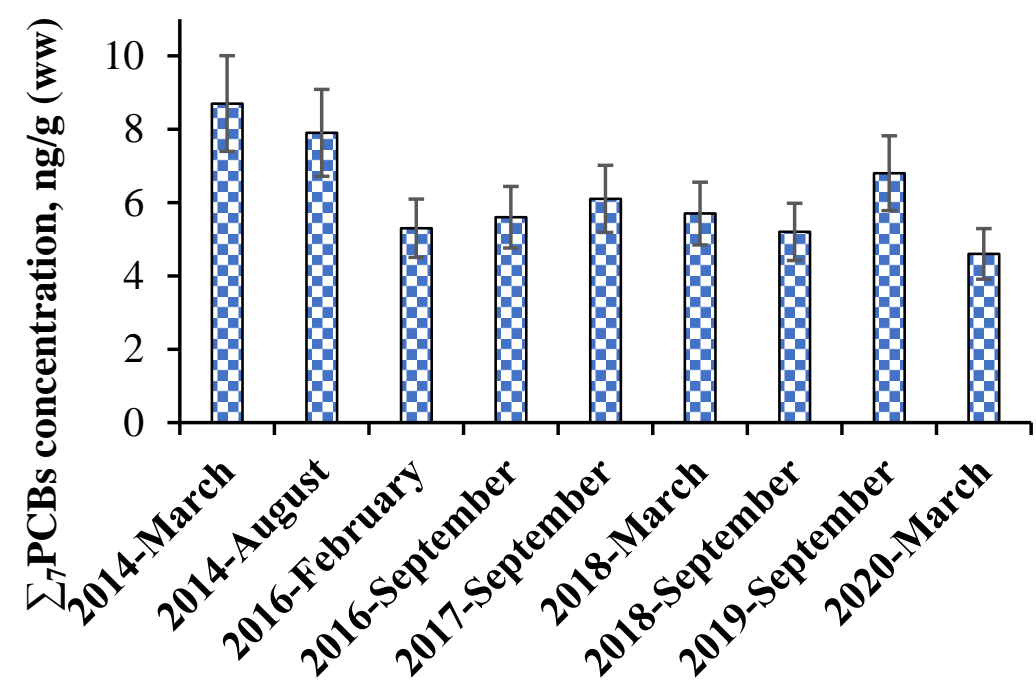

Seasons

Figure 3. Average concentrations of $\sum_{7} \mathrm{PCBs}$ in specimens of C. migratorius (per season) collected during the monitoring of PCBs in Baikal water.

Biomonitoring of PCBs in the lake water revealed five dl-congeners: 105, 114, 123, 126, and 156, which were present in the water below the LOQ of the method used to analyze the water. The total concentrations of dl-congeners in C. migratorius ranged from 1.3 to $1.7 \mathrm{ng} / \mathrm{g}(\mathrm{ww})$. The most toxic congener, 126 (the toxicity equivalence factor, $\mathrm{TEF}_{2005}$ is 0.1 ), was found in single individuals of the older age group (4 out of the 46 investigated individuals), reaching $0.5 \mathrm{ng} / \mathrm{g}(\mathrm{ww})$.

The age of fish is a critical biomonitoring factor, since the concentration of PCBs in individuals of the older age group increases [31]. During the biomonitoring, we chose individuals of $C$. migratorius aged from three to seven years. In this group of fish, the level of concentration of $\Sigma_{7} \mathrm{PCBs}$ changes insignificantly: $\sum_{7} \mathrm{PCBs}$ were 3.9 ( 3 year), 4.9 ( 5 year) and 5.4-5.6 (6-7 years) $\mathrm{ng} / \mathrm{g}(\mathrm{ww})$, and the proportion of congeners with a high degree of chlorination $(153,138,180)$ increased. In the muscle tissues of the individuals of the older age group (8 years, 2 specimens), the number of PCBs reached extreme values: $\Sigma_{7} \mathrm{PCBs}$ to $32 \mathrm{ng} / \mathrm{g}(\mathrm{ww})$ and $\Sigma_{\mathrm{dl}}$ PCBs to $9.0 \mathrm{ng} / \mathrm{g}(\mathrm{ww})$.

\subsection{Assessment of the PCB Concentration in the Water of Lake Baikal}

Global atmospheric transport is the dominant source of PCBs in the aquatic ecosystem of Lake Baikal. Therefore, the assessment of the concentrations of pollutants of this class in Baikal water by the concentrations of indicator congeners is reasonable and provides adequate results [65]. We carried out a comparative statistical analysis to study the influence 
of the year and season of sampling, locations of sampling stations in the pelagic zone of the lake and layers of the water column, and the age and sex of omul on the ratio and concentrations of indicator congeners of PCBs detected in the water samples and tissues of C. migratorius. To identify relationships between the concentrations of PCBs in Baikal water and C. migratorius, selected as a bioindicator of PCBs, a correlation analysis of the results of determining PCBs in water and C. migratorius was carried out.

\subsubsection{Statistical Analysis of the Results of 'Conventional' Monitoring}

The results of the PERMANOVA analysis (Table S6) indicated that among all studied factors only year and month of sampling significantly influenced the concentrations of the investigated PCB congeners, including $\Sigma_{7} \mathrm{PCBs}$, in Baikal water (year factor- $\mathrm{R}^{2}=0.163$; month factor $-\mathrm{R}^{2}=0.074 ; p$-value $\left.<0.05\right)$. At the same time, based on the coefficients of the $R^{2}$ covariation, the sampling year factor had the maximum effect on the concentrations of PCBs. Further data analysis by PCA based on the PERMANOVA results was carried out for the values averaged by the factors of the pelagic zone of the lake's basin and sampling depth.

The analysis of the results of the determination of PCB indicator congeners by PCA revealed that all data were divided into two groups (Figure 4a). The first group in the second quarter of the coordinate plane included the average data obtained in September 2016, May 2018-2019, and June and September 2020-2021. All points of this group were characterised by minimum concentrations of all indicator congeners and $\Sigma_{7} \mathrm{PCB}$ concentration ranging from $\leq 0.11$ to $0.47 \mathrm{ng} / \mathrm{L}$. The second group (the first quarter of the coordinate plane) includes the data obtained in May 2016 and September 2019. These data referred to extreme concentrations of all indicatory congeners and $\Sigma_{7} \mathrm{PCBs}(1.3-2.0 \mathrm{ng} / \mathrm{L})$ relative to the minimum level determined during the monitoring between 2015 and 2021.

On the PCA biplot (Figure 4a), the PCB concentration gradient vectors form a codirectional group that includes all investigated indicator congeners of PCBs and $\Sigma_{7} \mathrm{PCBs}$, except for congener 28 (a congener group with a positive correlation). The vector of congener 28 is directed almost perpendicular to the main group, and the concentration of this pollutant depends (correlates) to a lesser extent on the concentrations of other indicator PCBs. Perhaps, the sources of congener 28, its further fate in the aquatic ecosystem, and (or) congener properties (the minimum hydrophobicity and the maximum water solubility among indicator congeners) affect its concentration in Baikal water.

The PCA data on the concentrations of PCBs in Baikal water allowed us to draw the following conclusions: (i) an increase or a decrease in all indicator congeners, except for congener 28 and the concentration of $\Sigma_{6} \mathrm{PCBs}$, occurred synchronously; (ii) within the framework of conventional monitoring, the assessment of the PCB concentrations in Baikal water based on the total concentration of six indicator congeners $\left(\Sigma_{6} \mathrm{PCBs}\right.$, excluding congener 28) would meet more stringent criteria. 
a) Baikal water

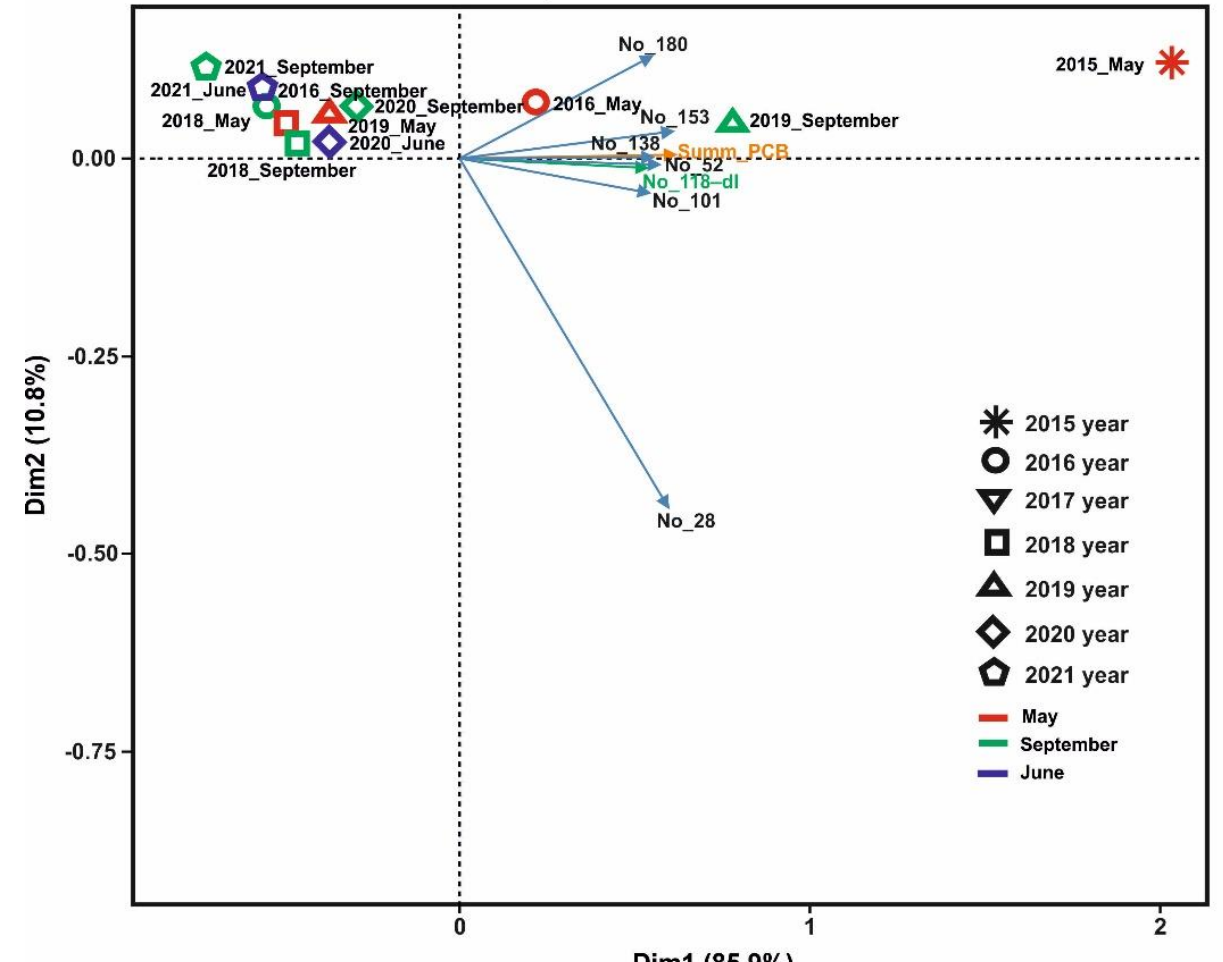

b) Baikal omul

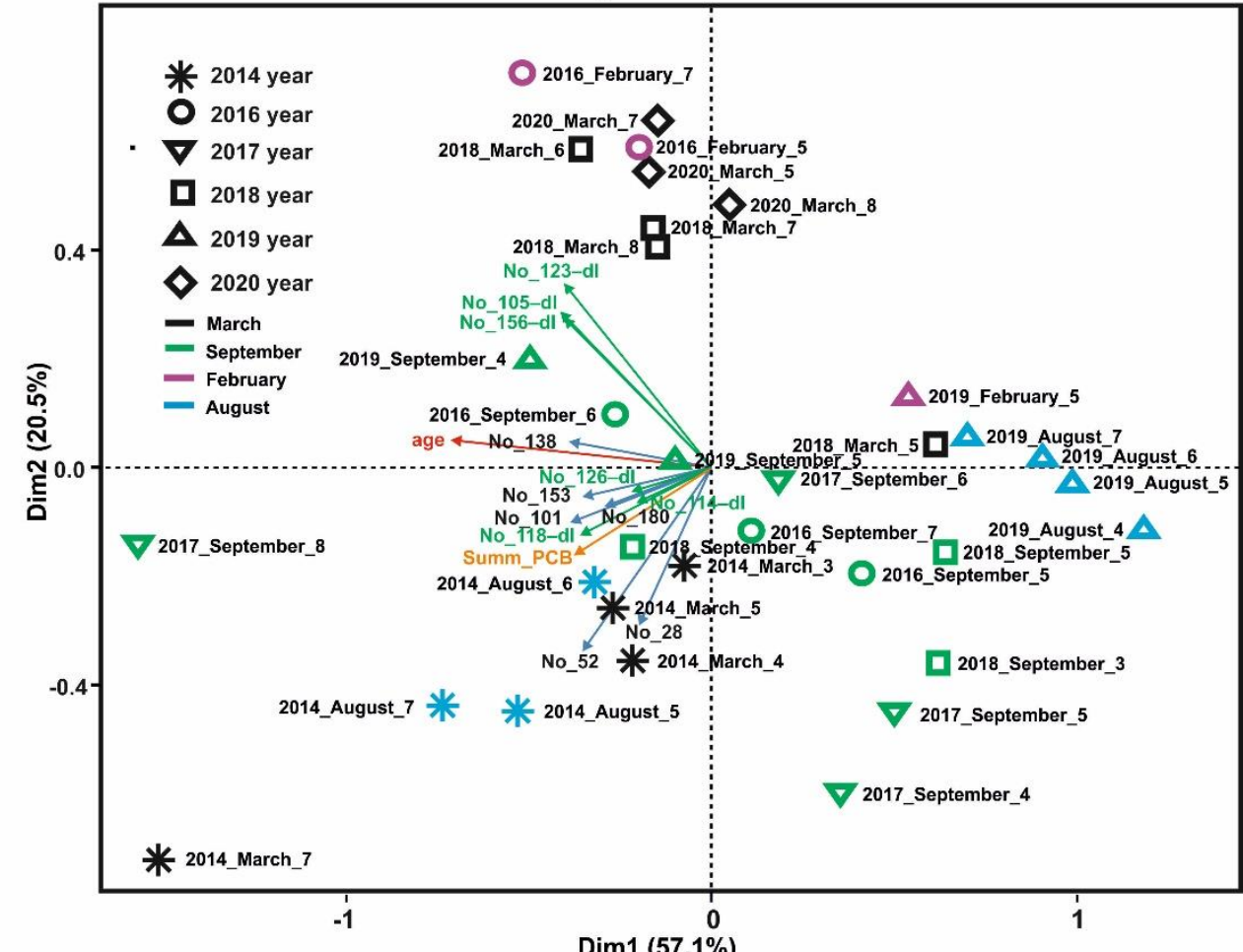

Figure 4. Results of the concentration distribution analysis of the investigated PCB types and the total PCB concentration based on PCA. (a) Analysis of water samples: point on the plane characterise the average $\mathrm{PCB}$ concentrations in Baikal water (entire water area of the lake) by the year and month of sampling (a point is the average PCB concentration in water samples taken in a certain month of one year); (b) analysis of the distribution of PCB concentrations in omul specimens: points on the plane characterise the average PCB concentrations in omul by the year, month, and age of the individuals (a point is the average PCB concentration in individuals of the same age collected in the same year and the same month). Vectors on the planes show the directions of the concentration gradients of the investigated PCB types (blue vectors and green vectors are dioxin-like PCBs), the total PCB concentration (orange vectors), and the age of omul individuals (red vector). 


\subsubsection{Statistical Analysis of Biomonitoring Results}

Based on the PERMANOVA data (Table S7), among all studied factors, the year and month of sampling and the age of individuals (year factor $-\mathrm{R}^{2}=0.193$; month factor- $R^{2}=0.107$; age factor $-R^{2}=0.075 ; p$-value $\left.<0.05\right)$ significantly influenced the concentrations of PCBs in the muscle tissue of $C$. migratorius. The $\mathrm{R}^{2}$ covariation coefficients indicated that the year of sampling was the main factor of influence followed by the less significant month of sampling and the age of fish (Figure $4 \mathrm{~b}$ ). As the sex of the C. migratorius individuals was not a critical factor $\left(R^{2}=0.002\right)$, PCA for $C$. migratorius was based on the sex-averaged data.

PCA of the concentrations of PCB congeners in C. migratorius distinguished three groups of averaged data (Figure $4 \mathrm{~b}$ ). The first group is located in the upper part of the coordinate plane at the border of the first and second quarters and included the data on $C$. migratorius caught in February 2016 and March 2018 and 2020. The age of the individuals in this group ranged from five to eight years.

All fish from this group were characterised by high dl-PCB concentrations ranging from 1.0 to $2.2 \mathrm{ng} / \mathrm{g}(\mathrm{ww})$, whose proportion in $\Sigma_{7} \mathrm{PCBs}$ reached $33 \%$, and by relatively low total concentrations of congeners 28 and 52, ranging from 1.1 to $2.6 \mathrm{ng} / \mathrm{g}$ (ww). Notably, this group of the $C$. migratorius fish was caught in the spring during the freezing period on the lake after the winter lifecycle with the corresponding feeding structure [66].

The second group of data located at the border of the first and fourth quarters of the coordinate plane included the results of the determination of PCB concentrations in C. migratorius that were caught at the end of the feeding period in August and September of 2016, 2017, 2018, and 2019. In this group of specimens, the concentration of PCBs was in the $\Sigma_{7} \mathrm{PCB}$ range from 5.2 to $6.8 \mathrm{ng} / \mathrm{g}$ (ww) with the concentrations of $\Sigma_{\mathrm{dl}} \mathrm{PCBs}$ ranging from 0.7 to $1.2 \mathrm{ng} / \mathrm{g}(\mathrm{ww})$. The age of the individuals was from four to seven years and predominated by five-year-olds. The group of points in the fourth coordinate plane includes the data on the $C$. migratorius specimens that differed in high concentrations of 'light' congeners 28 and 52 , with up to $33 \%$ of the $\Sigma_{7} \mathrm{PCB}$ concentration.

In the third quarter of the coordinate plane, there was the third group of the data on $C$. migratorius caught in March and August 2014 and September 2018. The presence of PCBs in this group was characterised by the maximum concentrations of $\Sigma_{7}$ PCBs ranging from 6.8 to $8.7 \mathrm{ng} / \mathrm{g}(\mathrm{ww})$ with the dominance of congeners 28 and 52 in the total proportion, with $50 \%$ of $\Sigma_{7}$ PCBs. Individual points in this part of the coordinate plane characterised the $C$. migratorius individuals caught from March to August 2014 and in September 2017. PCBs detected in these fish specimens had high concentrations of $\Sigma_{7} \mathrm{PCBs}$, from 10 to $13 \mathrm{ng} / \mathrm{g}$ $(w w)$. Noteworthy was the result of the determination of PCBs in an eight-year-old $C$. migratorius individual. The PCB concentrations in this individual reached extreme values: $\Sigma_{7} \mathrm{PCBs} 32 \mathrm{ng} / \mathrm{g}(\mathrm{ww})$ and $\Sigma_{\mathrm{dl}} \mathrm{PCBs} 9.0 \mathrm{ng} / \mathrm{g}(\mathrm{ww})$, with minimum total concentrations of 'light' congeners 28 and 52 at less than $7.0 \%$ of $\Sigma_{7}$ PCBs.

On the PCA biplot (Figure $4 \mathrm{~b}$ ), the gradient vectors of average data on the PCB concentrations in C. migratorius formed three codirectional groups. The first group included the vectors of indicator congeners 138,153, and 101, and dl-congeners 126, 118, and 114, together with the vector of the age of individuals. All these characteristics, including the age of individuals, were positively correlated with each other. The second group included the vectors of congeners 28 and 52, whose concentrations were associated with a strong positive correlation with each other and a weaker positive correlation with the vectors of the first group. The third group of vectors included dl-congeners 156, 105, and 123, whose concentrations were associated with each other by a strong positive correlation and a weaker positive correlation with the vectors of the first group.

The vectors of the third and second groups were almost perpendicular to each other. Therefore, the concentrations of PCBs in the specimens from these groups were not correlated and interconnected with each other.

The evaluation of C. migratorius as a bioindicator of PCBs in Baikal water by PCA based on the analysis of the results of the detection of PCBs in its tissues revealed that (i) the 
age of the fish determined the concentrations of indicator congeners with a high degree of chlorination (101, 138, and 153) and dioxin-like congeners 114 and 118, including the most toxic congener 126; (ii) the concentrations of 'light' congeners 28 and 52 did not depend on the age of the fish and were not associated with the accumulation of other congeners.

\subsubsection{Analysis of Correlations}

The heatmap in Figure 5a shows an analysis of correlations between the concentrations of various $\mathrm{PCB}$ congeners and the $\Sigma_{7} \mathrm{PCB}$ concentrations in Baikal water. Between all concentrations of PCBs and $\Sigma_{7} \mathrm{PCBs}$, there were significant positive $(p<0.05)$ pairwise correlations with correlation coefficients ranging from 0.6 to 0.9 . Among all correlation clusters, a group of indicators stood out, including the concentrations of congeners 52 , 101 , and 153, dl-congener 118 and $\Sigma_{7}$ PCBs in the water with a high pairwise correlation (correlation coefficient from 0.85 to 0.98 ). Additionally, there was the correlation group of congeners 138 and 180. The correlation coefficients of the concentrations of these congeners with each other, with the concentrations of other congeners, and with $\Sigma_{7} \mathrm{PCBs}$ had lower values (from 0.75 to 0.85 ). The concentration of congener 28 was distinguished by the minimum correlation coefficient with the concentration of congener 180 (0.6). The results of the correlation analysis of the indicator PCBs in Baikal water indicated a strong agreement in the change in the concentrations of chlorobiphenyls $(28,52,101$, and 118) with each other and with the concentration of $\Sigma_{7} \mathrm{PCBs}$. An increase or a decrease in the concentrations of one of these congeners was accompanied by an increase or a decrease in the concentrations of all congeners from the abovementioned group. The concentrations of congeners 138 and 180 were less correlated with the concentrations of other PCBs. Obviously, various factors determined the qualitative composition of PCB congeners in Baikal water: $\mathrm{PCB}$ sources (local and long-range atmospheric transport), water solubility and hydrophobicity, sorption on the particles of the solid phase of the water column, and transition to the bottom sediments.

PCBs identified in the tissues of $C$. migratorius were characterised by more complicated pairwise correlations between the concentrations of different congeners compared to the results of the corresponding analysis of PCBs in Baikal water (Figure 5b). Positive values of the correlation coefficients above $0.5(p<0.05)$ were classified as significant. Based on the range of pairwise correlation coefficients and the clusterisation results, all PCB congeners were divided into three groups.

The first group included the concentrations of congeners 153, 180, 101, and 118 together with the concentration of $\Sigma_{7} \mathrm{PCBs}$. In this group, the concentrations of the components were positively correlated with each other and with the rest of the PCB congeners. The second group included congener 138 and dl-congeners 105, 123, and 156. The concentrations of congeners from this group were associated by high correlations with each other $(r>0.7)$ and a small correlation with congeners from the first group $(0.3<\mathrm{r}<0.6)$. There was no significant correlation between the concentrations of congeners from the second group and congeners 28 and 52, and dl-congeners 114 and 126. The third group included congeners 114 and 126 and dl-congeners 114 and 126 that had high correlations with each other $(r>0.7)$ and weak correlations with congeners from the first group $(0.3<r<0.6)$. There was no significant correlation between the concentrations of congeners from the third and the second groups. The ages of the $C$. migratorius individuals were significantly correlated with the concentrations of congeners 138, 101, and 153 and dl-congeners 123, 105, and 118. At the same time, the correlation coefficients were relatively small, from 0.3 to 0.5 . 


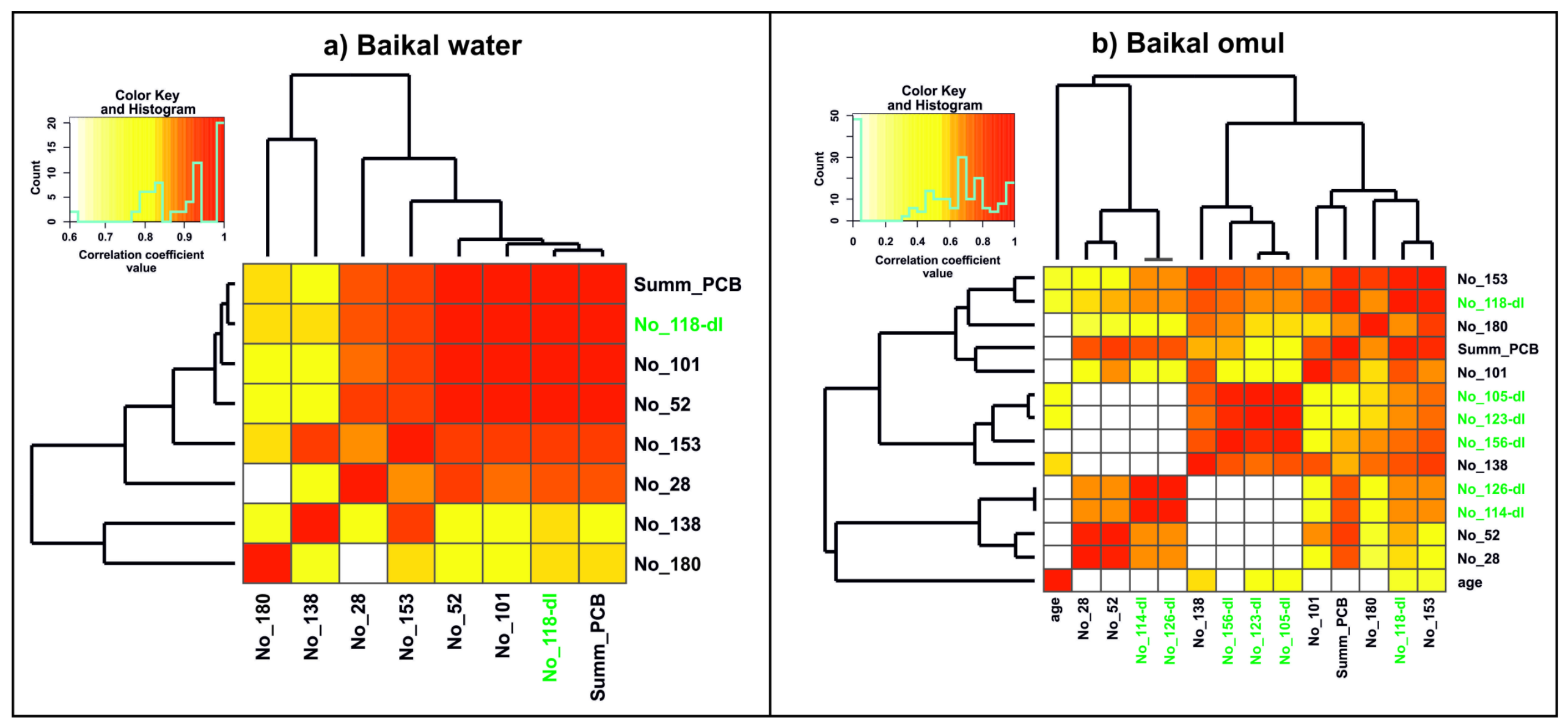

Figure 5. Heatmaps reflecting the calculations of pairwise correlation coefficients (a) between the concentrations of indicator congeners and $\Sigma_{7}$ PCBs in Baikal water samples and (b) between the concentrations of indicator congeners and $\Sigma_{7} \mathrm{PCBs}$ in the tissues of $C$. migratorius and the age of the investigated omul individuals from Lake Baikal. Rows and columns in the heatmaps cluster by the proximity of the spectra of the correlation coefficients. Insignificant values of the correlation coefficients are replaced with zero values; dl-PCBs are marked in green. 
The division of the investigated congeners in C. migratorius into three groups was likely related to the mechanisms of their accumulation and metabolism in fish bodies. Some indicator congeners of PCBs had a wide range of hydrophobicity properties $\left(\log \mathrm{K}_{\mathrm{ow}}=5.67-7.36\right.$ [67]), and the level of their accumulation in the tissues of fish corresponded to their hydrophobicity. For this reason, congeners 28 and 52 predominated in the water, having the minimum $\log \mathrm{K}_{\mathrm{ow}}$ values among indicator congeners. The concentrations of congeners with the maximum numbers of chlorine atoms in the structure increased with the age of individuals. Consequently, the ratio of congeners in fish tissues did not reflect their ratio in water samples. The change in the ratio of congeners in fish tissues was likely owing to not only hydrophobicity of chlorobiphenyls but also to the faster metabolism of congeners with a low degree of chlorination [68]. It was also due to the barriers that occurred during their passage through lipid membranes of cells and (or) to the adsorption caused by the low water solubility $[69,70]$.

Analysis of the relationship between the levels of PCB concentrations in Baikal water and the tissues of $C$. migratorius averaged over years using the Mantel test (Figure 6a) revealed the low and insignificant $(p>0.05)$ Spearman correlation coefficient. This indicated that the change in the concentrations of PCBs in Baikal water did not lead to similar changes in the level of the PCB concentrations in the tissues of $C$. migratorius. The relationship between average annual concentrations of PCBs in the water and their accumulation in the tissues of $C$. migratorius was not statistically confirmed.

Pairwise correlation analysis between average annual concentrations of PCBs in Baikal water and C. migratorius (Figure 6b) also did not revealed significant correlations. All pairwise correlation coefficients between the concentration of the investigated PCB congeners in the water and their accumulation in C. migratorius did not significantly differ from zero $(p>0.05)$, confirming the conclusions of the Mantel test.

For the Mantel test and correlation analysis between the pairs of dependent and insignificant variables, we took the same-year data on both the water and C. migratorius. Perhaps, due to this fact, there was no relationship between the concentrations of PCBs in the water and their accumulation in the tissues of $C$. migratorius. Omul accumulates PCBs gradually during several years, and not only the current concentration of PCBs but also the impact of PCBs in previous years determines the concentrations of the investigated congeners in the tissues of $C$. migratorius. Identification of this relationship requires long series of observations (ten years or more), taking into account other factors that are difficult to consider. These factors affect the processes of PCB accumulation in omul during the observation period, particularly, the change in the qualitative composition of dominant phytoplankton and zooplankton species that are part of $C$. migratorius food web. They also lead to interannual changes in temperature and ice regimes of the lake, which change the speed and direction of migrations and feeding behaviour in fish. Moreover, various factors also affect the qualitative composition of $\mathrm{PCB}$ congeners in the water of the lake: $\mathrm{PCB}$ sources (local and long-range atmospheric transport), hydrophobicity and water solubility of PCBs, their sorption on particles of the solid phase of the water column, and transition to the bottom sediments. 


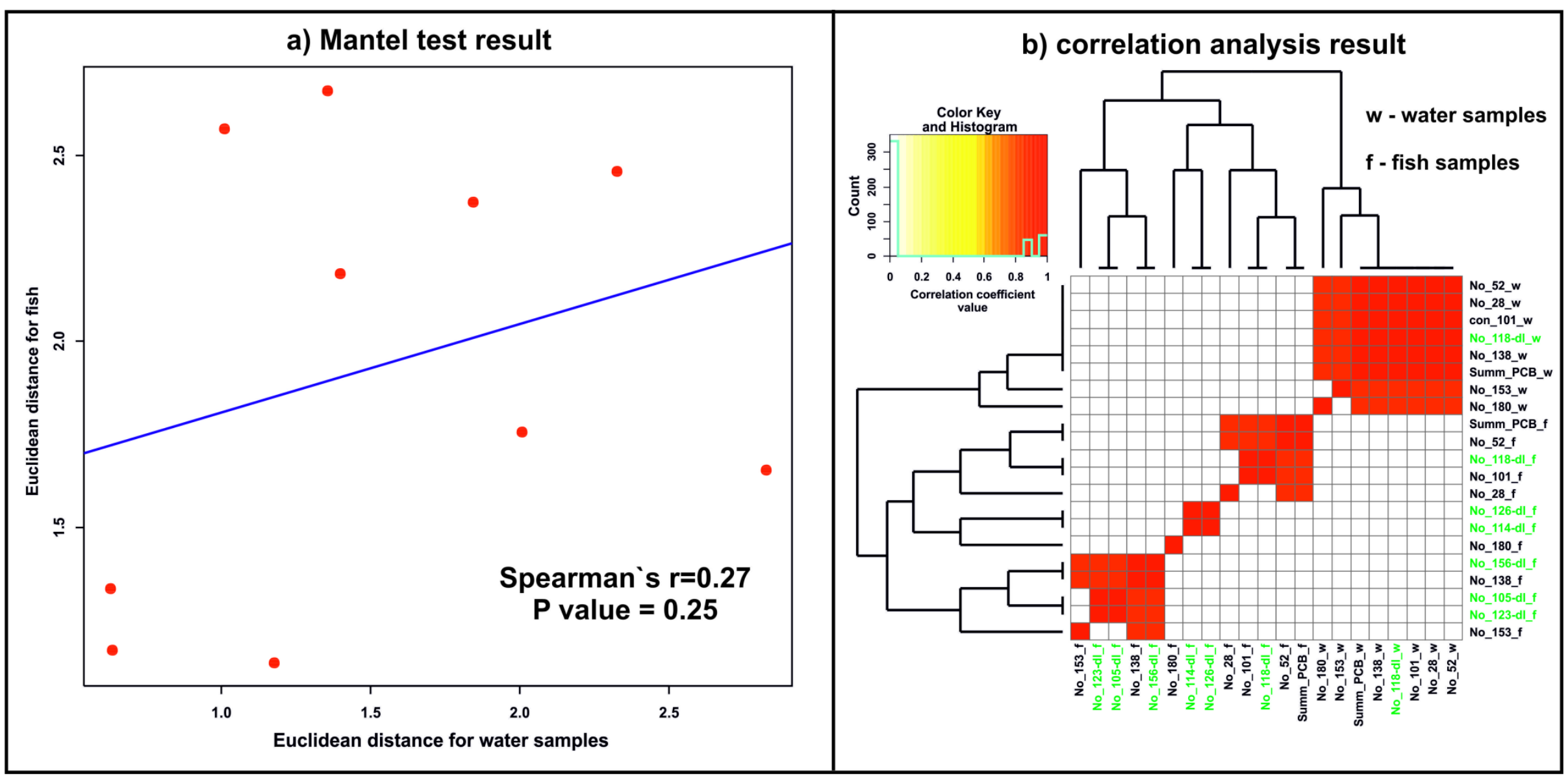

Figure 6. (a) Results of the analysis of the relationship between the concentrations of the investigated congeners and $\Sigma_{7}$ PCBs in the water and C. migratorius using the Mantel test (the analysis was carried out for values averaged by years). (b) Heatmaps reflect the calculations of pairwise correlation coefficients between the concentrations of indicator congeners and $\Sigma_{7} \mathrm{PCBs}$ in the water and C. migratorius (the analysis was carried out for values averaged over years). Rows and lines on the heatmap are clustered based on the proximity of spectra of correlation coefficients; insignificant values of the correlation coefficients were replaced with zero values; dl-PCBs are marked in green. 


\subsubsection{Toxicity Equivalence for Dioxin-like PCBs}

In Baikal water, we did not identify congeners of polychlorinated dibenzo-p-dioxins and dibenzofurans exceeding the detection limit of $0.01 \mathrm{pg} / \mathrm{L}$ [11]. Only one dl-PCB congener, 118, was identified during the monitoring of PCBs between 2015 and 2021. Its concentrations ranged from $\leq 10$ to $110 \mathrm{pg} / \mathrm{L}$. In seasons with the extreme concentrations of PCBs, its concentration in the water increased to $350 \mathrm{pg} / \mathrm{L}$. The toxicity of this congener was assessed by the dioxin toxicity equivalents (TEQs) for dl-PCB within the WHO-TEQ ${ }_{(2005)}$ $\mathrm{pg} / \mathrm{L}$ range from $3 \times 10^{-4}$ to $3.3 \times 10^{-3}$. In seasons with the extreme concentrations, the WHO-TEQ ${ }_{(2005)} \mathrm{pg} / \mathrm{L}$ value reached 0.01 in May 2015 in the southern basin and $7 \times 10^{-3}$ in September 2019 in the northern basin of Lake Baikal. In the muscle tissues of C. migratorius, the total toxicity equivalent of the detected dl-congeners (except for congener 126) was within the WHO-TEQ (2005) $\mathrm{pg} / \mathrm{g}(\mathrm{ww})$ range from 0.03 to 0.06 , and for congener 126, the value was two orders of magnitude higher, up to 4.7.

3.3.5. Comparative Analysis of the PCB Concentrations in the Surface Water of the Background Sites and in Bioindicator Fish

Currently, there is no common criterion for assessing the pollution of water by PCBs. According to the interim environmental quality standard (EQS), the PCB concentration in the surface waters of the European Union should not exceed $1 \mathrm{ng} / \mathrm{L}$ [71]. According to the standards established in Russia, the PCB concentration in water bodies for drinking and domestic water use should not exceed $1000 \mathrm{ng} / \mathrm{L}$, but the PCB concentrations are not allowed in the water bodies for fishery purposes [72]. According to the standards of the US Environmental Protection Agency [73], the PCB concentration in water less than $14 \mathrm{ng} / \mathrm{L}$ does not pose a danger to aquatic organisms and human health.

The level of PCBs in Baikal water was higher than in the water from the Antarctic and Arctic regions but comparable with or much lower than the concentrations of PCBs in waters of the continental lakes such as Como (Italy), the Caspian Sea (northern part, Russia), and Lake Baiyangdian (China) (Table 1). The use of fish to assess the pollution of different water bodies by PCB pollutants based on the level of their accumulation in fish was a rather difficult task due to the discrepancy between the characteristics of fish (age and the number of lipids) as well as to the methods used for the detection of PCBs (number of congeners).

We compared the accumulation level of $\sum_{7} \mathrm{PCBs}$ in the muscle tissue of $C$. migratorius with the accumulation of $\sum_{7} \mathrm{PCBs}$ in S. trutta fario inhabiting alpine lakes of Southern and Central Europe. The species S. trutta fario was the closest to C. migratorius in terms of taxonomic characters. Individuals corresponding in age and lipid content were taken for comparison. Comparable levels of $\sum_{7} \mathrm{PCBs}$ in C. migratorius and Salmo trutta indicated the same concentration level of bioavailable PCBs in Baikal water and alpine lakes [30-33]. In the tissues of Salmo trutta from Lake Iseo and Lake Endine situated in the industrial regions of Northern Italy [22], the $\sum_{7} \mathrm{PCB}$ value was three to seven times higher than in $C$. migratorius: 2600, 1100, and $330 \mathrm{ng} / \mathrm{g}(\mathrm{lw})$, respectively.

Table 1. The concentrations of PCB congeners in the water from background sites and in the tissues of fish chosen as PCB bioindicators (ng/g, ww).

\begin{tabular}{cccc}
\hline Area & Year & PCBs in the Water, ng/L & References \\
\hline Arctic & 2011 & $\sum_{13}$ PCBs 0.0013-0.021 & {$[9]$} \\
Arctic Norway & 1999 & $\sum_{12}$ PCBs 0.023-0.129 & {$[74]$} \\
Canadian Archipelago & 2018 & $\sum$ PCBs 0.65-46 & {$[42]$} \\
Tropical Atlantic Ocean & 2021 & $\sum$ PCBs 0.0041 ng $/ \mathrm{L}$ & {$[12]$} \\
Antarctic, Victoria Land & $2011-2012$ & $\sum_{127}$ PCBs 0.046-0.143 & {$[74]$} \\
European alpine lakes & $2000-2001$ & $\sum_{7}$ PCBs 0.048-0.123 & {$[75]$} \\
Himalayas & 2007 & $\sum_{5}$ PCBs 0.02-0.45 & This study \\
Lake Baikal, Russia & $2015-2021$ & $\sum_{24-34}$ PCBs 1.4-9.7 & {$[77]$} \\
Lake Como, Italy & 2007 & $\sum_{7}$ PCBs 0.30; $0.26-0.34$ & {$[78]$} \\
Caspian Sea, Russia & 2002 & $\sum_{6}$ PCBs: 0.10-7.3 & {$[79]$} \\
Lake Baiyangdian, China & 2008 & $\sum_{39}$ PCBs 19-132 & \\
\hline
\end{tabular}


Table 1. Cont.

\begin{tabular}{|c|c|c|c|}
\hline Area & Year & PCBs in the tissues of fish, $\mathrm{ng} / \mathrm{g}$ ww & \\
\hline Lake Baikal, Russia & 2014-2020 & C. migratorius, $\sum_{7}$ PCBs 5.6; 4.9-6.3 & This study \\
\hline $\begin{array}{l}\text { Alpine lakes of Western } \\
\text { Europe }\end{array}$ & 2003-2004 & Salmo trutta, $\sum_{7}$ PCBs 6.3-13 & {$[30-33]$} \\
\hline $\begin{array}{l}\text { Southern Moravia, } \\
\text { Czech Republic }\end{array}$ & 2013 & $\begin{array}{c}\text { Carp, } \sum_{7} \text { PCBs 2.4-14, } \\
\text { Bream, } \sum_{7} \text { PCBs 8.0-210 } \\
\text { Pike perch. } \sum_{7} \text { PCBs 2.4-4 }\end{array}$ & [27] \\
\hline $\begin{array}{c}\text { Baltic Sea, } \\
\text { Polish fishing area }\end{array}$ & 2012 & $\begin{array}{l}\text { Salmo salar, } \sum_{6} \text { PCBs } 7.7-61 \\
\text { Salmo trutta, } \sum_{6} \text { PCBs: } 31-56 \\
\text { Gadus morhua callarisa, } \\
\sum_{6} \text { PCBs: } 0.07-2.8\end{array}$ & [80] \\
\hline $\begin{array}{l}\text { Legally binding } \\
\text { documents, EU }\end{array}$ & 2019 & $\begin{array}{l}\text { Food products, muscle meat of fish, } \\
\qquad \sum_{6} \text { PCBs } 75\end{array}$ & [81] \\
\hline Area & Year & $\begin{array}{l}\text { PCBs in the tissues of fish, } \\
\text { pg WHO-TEQ/g lw }\end{array}$ & \\
\hline Lake Baikal, Russia & 2014-2020 & C. migratorius $0.03-0.06$ & This study \\
\hline $\begin{array}{c}\text { Baltic Sea, } \\
\text { Polish fishing area }\end{array}$ & 2003 & $\begin{array}{c}\text { Salmo salar, } 1.0-7.4 \\
\text { Salmo trutta, } 4.2-9.0 \\
\text { Gadus morhua callarisa, } 0.62-0.67\end{array}$ & [80] \\
\hline $\begin{array}{l}\text { Legally binding } \\
\text { documents, EU }\end{array}$ & 2019 & $\begin{array}{l}\text { Food products, muscle meat of fish, } \\
\qquad 3.0\end{array}$ & [81] \\
\hline
\end{tabular}

In the muscle tissues of $C$. migratorius, the total toxicity of four dl-congeners 118, 105, 123 , and $156 \mathrm{did}$ not exceed the WHO-TEQ (2005) $\mathrm{pg} / \mathrm{g}(\mathrm{ww})$ value of 0.06 . The higher toxicity level of the detected dl-congeners, up to the WHO-TEQ ${ }_{(2005)} \mathrm{pg} / \mathrm{g}(\mathrm{ww})$ value of 4.7, was observed in the individuals of the older age group (eight years and older) due to the accumulation of congener 126. In the fish from the Baltic Sea, the total toxicity equivalent of dl-congeners was by two orders of magnitude higher than in C. migratorius (WHO-TEQ (1997) $\mathrm{pg} / \mathrm{g}(\mathrm{ww})$ from 0.64 to 6.0) [80].

\subsection{Opportunities for Monitoring}

The conventional monitoring of PCBs in surface waters with pollutant concentrations close to the background level suggests two stages. The first stage includes water sampling in different seasons, from different depths, and at different stations, taking into account the presence of potential pollution sources, and determining the PCB concentrations in the samples The second stage includes analysis of the relationship between the detected concentrations of PCBs and sampling factors (year, season, station location, and depth of water layer). Based on the correlation analysis of the data, the congener(s) is (are) selected as indicators (indices) of the group with high positive correlations between the concentrations of congeners in the group. After that, during systematic monitoring, the concentrations of PCBs in a water body are estimated from the concentration of a congener selected as an indicator.

Biomonitoring provides detection of congeners in a water body, whose concentrations are below the LOQ level of the method used, in particular, dl-PCBs. A biological object chosen as a bioindicator must meet all the criteria that bioindicator objects should have [16]. Based on the correlation analysis of the data, a congener is also selected in the groups with high positive correlations between the concentrations of dl-PCBs characterised by higher concentrations and, hence, higher reliability and accuracy of detection. Thereafter, the current monitoring of dl-PCBs is possible for one (several) selected congener(s), a sharp increase in the concentration of which may trigger a more detailed analysis of the monitoring results.

\section{Conclusions}

The results of assessing concentrations of PCBs in the water of Lake Baikal obtained within the framework of conventional monitoring and biomonitoring confirmed the background level of PCB concentrations. The average concentration and statistically significant 
range of the detected $\Sigma_{7} \mathrm{PCB}$ concentrations in Baikal water were 0.30 and $0.26-0.34 \mathrm{ng} / \mathrm{L}$, respectively. This concentration level was higher than in the waters from the Arctic and Antarctic areas but is comparable with or much lower than the PCB concentrations in the waters of continental lakes. Biomonitoring of PCBs using C. migratorius as a bioindicator in the lake water revealed five dl-congeners that were present in the water below LOQ of the method used. The most toxic congener 126 (the toxicity equivalence factor, $\mathrm{TEF}_{2005}$ is 0.1 ) was found in single individuals of the older age group. The total concentrations of dlcongeners in C. migratorius ranged from 1.3 to $1.7 \mathrm{ng} / \mathrm{g}(\mathrm{ww})$. The total toxicity equivalent of the detected dl-congeners (except for congener 126) was within the $\mathrm{WHO}^{-T E Q} \mathrm{Q}_{(2005)} \mathrm{pg} / \mathrm{g}$ $(\mathrm{ww})$ range from 0.03 to 0.06 . This level of dl-PCBs corresponded to their concentrations in fish inhabiting European alpine lakes but was much lower than in fish from the Baltic Sea.

In the course of choosing a system for monitoring PCBs in Baikal water, the preliminary stage of the study included water sampling at 21 stations (water surface area $31,700 \mathrm{~km}^{2}$ ). Based on the analysis of the monitoring results, five reference stations were selected for water sampling: $3,6,11,16$, and 19 . The reduction in the number of stations did not distort the characteristics for the assessment of the PCB concentrations in the lake water. The control of PCBs in the surface water was possible by determining the concentrations of two of the seven indicator congeners, 52 and 101, because the concentrations of these congeners were highly correlated with each other, all indicator congeners, and $\Sigma_{7} \mathrm{PCBs}$. They also have the maximum level of concentrations in water samples, and homogenous peaks of PCBs were recorded in chromatograms. According to the data on the correlation analysis, the congeners identified in C. migratorius were divided into three groups, and we proposed indicator congeners for these groups: congener 101 (correlation group from congeners 118-dl, 153, and 180), 138 (correlation group of congeners 105-dl, 123-dl, and 156-dl) and 52 (correlation group of congeners 28, 114-dl, and 126-dl).

Supplementary Materials: The following supporting information can be downloaded at: https: / / www.mdpi.com/article/10.3390/app12042145/s1, Table S1: Sampling stations, Table S2: Characteristics of the C. migratorius individuals caught in the course of biomonitoring, Table S3: Concentrations of indicator congeners in the water, ng/L, Table S4: Concentrations of indicator congeners in C. migratorius, ng/g (ww), Table S5: Concentrations of dl-congeners in C. migratorius. ng/g (ww), Table S6: Results of the analysis of the data from conventional monitoring by the PERMANOVA method, Table S7: Results of the analysis of the data from biomonitoring by the PERMANOVA method, Table S8: Relative error statistics for repeated measurements of PCB concentrations in water and C. migratorius, Table S9: Statistical parameters of the average values of PCB concentrations in water and C. migratorius.

Author Contributions: A.G.G.: concept of the study, methodology, writing, and preparation of the original draft; O.V.K.: water and fish sampling, chromatography-mass spectrometric analysis; Y.S.B.: statistical analysis. All authors have read and agreed to the published version of the manuscript.

Funding: This study was carried out within the framework of the State Task, project No. 0279-20210005 (121032300224-8).

Institutional Review Board Statement: Not applicable.

Informed Consent Statement: Not applicable.

Data Availability Statement: All primary data are available in tables Tables S3-S5.

Acknowledgments: Chromatography mass spectrometry analysis was carried out in the Shared Research Facilities for Physical and Chemical Ultramicroanalysis LIN SB RAS. The authors thank Vitaly A. Khutoryanskiy for the sampling of C. migratorius and Anatoly M. Mamontov for determining the age of fish carried out within the framework of the project by the Russian Foundation for Basic Research and the Government of the Irkutsk Region, No. 17-45-388077 r_a, and Elena V. Dzyuba for advice on preparing fish for analysis.

Conflicts of Interest: The authors declare no conflict of interest. 


\section{References}

1. World Economic Forum. Global Risks, 10th ed.; World Economic Forum: Geneva, Switzerland, 2015; Available online: https: / / www.weforum.org/reports/global-competitiveness-report-2015 (accessed on 24 September 2021).

2. Kirschke, S.; Avellán, I.; Bärlund, T.; Bogardi, J.J.; Carvalho, L.; Chapman, D.; Dickens, C.W.S.; Irvine, K.; Lee, S.B.; Mehner, T.; et al. Capacity challenges in water quality monitoring: Understanding the role of human developmet. Environ. Monit. Assess. 2020, 192, 298. [CrossRef] [PubMed]

3. Wong, F.; Hung, H.; Dryfhout-Clark, H.; Aas, W.; Bohlin-Nizzetto, P.; Breivik, K.; Mastromonaco, M.N.; Lundén, E.B.; Ólafsdóttir, K.; Sigurðsson, Á.; et al. Time trends of persistent organic pollutants (POPs) and Chemicals of Emerging Arctic Concern (CEAC) in Arctic air from 25 years of monitoring. Sci. Total Environ. 2021, 775, 145109. [CrossRef] [PubMed]

4. Wolska, L.; Mechlinska, A.; Rogowska, J.; Namiesnik, J. Sources and fate of PAHs and PCBs in the marine environment. Crit. Rev. Environ. Sci. Technol. 2012, 42, 1172-1189. [CrossRef]

5. Cipro, C.V.Z.; Colabuono, F.I.; Taniguchi, S.; Montone, R.C. Persistent organic pollutants in bird, fish and invertebrate samples from King George Island. Antarct. Antarct. Sci. 2013, 25, 545-552. [CrossRef]

6. Gakuba, E.; Moodley, B.; Ndungu, P.; Birungi, G. Occurrence and significance of polychlorinated biphenyls in water, sediment pore water and surface sediments of Umgeni River, KwaZulu-Natal, South Africa. Environ. Monit. Assess. 2015, 187, 568. [CrossRef]

7. Stockholm Convention. About Persistent Organic Pollutants (CO3). As Amended in 2017. Available online: http://Downloads / UNEP-POPS-COP-CONVTEXT-2017 (accessed on 21 December 2021).

8. OSPAR Commission. Protecting and Conserving the North-East Atlantic and Its Resources. Available online: http://www.ospar. org/convention (accessed on 21 December 2021).

9. Carrizo, D.; Gustafsson, Ö. Distribution and Inventories of Polychlorinated Biphenyls in the Polar Mixed Layer of Seven Pan-Arctic Shelf Seas and the Interior Basins. Sci. Technol. 2011, 45, 1420-1427. [CrossRef] [PubMed]

10. Lohmann, R.; Dachs, J. World Seas: An Environmental Evaluation, 2nd ed.; Volume III: Ecological Issues and Environmental Impacts; Academic Press: Cambridge, MA, USA, 2019; pp. 269-282. [CrossRef]

11. Samsonov, D.P.; Kochetkov, A.I.; Pasynkova, E.M.; Zapevalov, M.A. Levels of Persistent Organic Pollutants in the Components of the Lake Baikal Unique Ecosystem. Russ. Meteorol. Hydrol. 2017, 42, 345-352. [CrossRef]

12. Lohmann, R.; Markham, E.; Khalova, I.; Sunderland, E.M.; Kukucka, P.; Pribylova, P.; Gong, X.; Pockalny, R.; Yanishevsky, T.; Wagner, C. Trends of Diverse POPs in Air and Water Across the Western Atlantic Ocean: Strong Gradients in the Ocean but Not in the Air. Environ. Sci. Technol. 2021, 55, 9498-9507. [CrossRef]

13. Lohmann, R.; Muir, D. Global Aquatic Passive Sampling (AQUA-GAPS): Using passive samplers to monitor POPs in the waters of the world. Environ. Sci. Technol. 2010, 44, 860-864. [CrossRef]

14. Reddy, A.V.B.; Moniruzzaman, M.; Aminabhavi, T.M. Polychlorinated biphenyls (PCBs) in the environment: Recent updates on sampling, pretreatment, cleanup technologies and their analysis. Chem. Eng. J. 2019, 358, 1186-1207. [CrossRef]

15. Muir, D.; Sverko, E. Analytical methods for PCBs and organochlorine pesticides in environmental monitoring and surveillance: A critical appraisal. Anal. Bioanal. Chem. 2006, 386, 769-789. [CrossRef] [PubMed]

16. Tanabe, S.; Subramanian, A. Bioindicators of POPs; University Press and Trans Pacific Press: Kyoto, Japan, 2006; 172p.

17. Manirakiza, P.; Covaci, A.; Nizigiymana, L.; Ntakimazi, G.; Schepens, P. Persistent chlorinated pesticides and polychlorinated biphenyls in selected fish species from Lake Tanganyika, Burundi, Africa. Environ. Pollut. 2002, 117, 447-455. [CrossRef]

18. Szlinder-Richert, J.; Barska, I.; Mazerski, J.; Usydus, Z. PCBs in fish from the southern Baltic Sea: Levels, bioaccumulation features, and temporal trends during the period from 1997 to 2006. Mar. Pollut. Bull. 2009, 58, 85-92. [CrossRef]

19. Szlinder-Richert, J.; Barska, I.; Usydus, Z.; Ruczynska, W.; Grabic, R. Investigation of PCDD/Fs and dl-PCBs in fish from the southern Baltic Sea during the 2002-2006 period. Chemosphere 2009, 74, 1509-1515. [CrossRef] [PubMed]

20. Jaikanlaya, C.; Settachan, D.; Denison, M.S.; Ruchirawat, M.; van den Berg, M. PCBs contamination in seafood species at the Eastern Coast of Thailand. Chemosphere 2009, 76, 239-249. [CrossRef]

21. Blocksom, K.A.; Walters, D.M.; Jicha, T.M.; Lazorchak, J.M.; Angradi, T.R.; Bolgrien, D.W. Persistent organic pollutants in fish tissue in the mid-continental great rivers of the United States. Sci. Total Environ. 2010, 408, 1180-1189. [CrossRef] [PubMed]

22. Piersanti, A.; Amorena, M.; Manera, M.; Tavoloni, T.; Lestingi, C.; Perugini, M. PCB concentrations in freshwater wild brown trouts (Salmo trutta trutta L) from Marche rivers, Central Italy. Ecotoxicol. Environ. Saf. 2012, 84, 355-359. [CrossRef]

23. Baptista, J.; Pato, P.; Pereira, E.; Duarte, A.; Pardal, M.A. PCBs in the fish assemblage of a southern European estuary. J. Sea Res. 2013, 76, 22-30. [CrossRef]

24. Cerveny, D.; Zlabek, V.; Velisek, J.; Turek, J.; Grabic, R.; Grabicova, K.; Fedorova, G.; Rosmus, J.; Lepic, P.; Randak, T. Contamination of fish in important fishing grounds of the Czech Republic. Ecotoxicol. Environ. Saf. 2014, 109, 101-109. [CrossRef] [PubMed]

25. Moraleda-Cibrián, N.; Carrassón, M.; Rosell-Melé, A. Polycyclic aromatic hydrocarbons, polychlorinated biphenyls and organochlorine pesticides in European hake (Merluccius merluccius) muscle from the Western Mediterranean Sea. Mar. Pollut. Bull. 2015, 95, 513-519. [CrossRef] [PubMed]

26. Net, S.; Henry, F.; Rabodonirina, S.; Diop, M.; Merhaby, D.; Mahfouz, C.; Amara, R.; Ouddane, B. Accumulation of PAHs, Me-PAHs, PCBs and total Mercury in sediments and Marine Species in Coastal Areas of Dakar, Senegal: Contamination level and impact. Inter. J. Environ. Res. 2015, 9, 419-432. 
27. Zelníčková, L.; Svobodová, Z.; Maršálek, P.; Dobšíková, R. Persistent organic pollutants in muscle of fish collected from the Nové Mlýny reservoir in Southern Moravia, Czech Republic. Environ. Monit. Assess. 2015, 187, 448-454. [CrossRef] [PubMed]

28. Froescheis, O.; Looser, R.; Cailliet, G.M.; Jarman, W.M.; Ballschmiter, K. The deep-sea as a regional global sink of semivolatile persistent organic pollutants? Part I: PCBs in surface and deep-sea dwelling fish of the North and South Atlantic and the Monterey Bay Canyon (California). Chemosphere 2000, 40, 651-660. [CrossRef]

29. Flanagan Pritz, C.M.; Schrlau, J.E.; Massey Simonich, S.L.; Blett, T.F. Contaminants of emerging concern in fish from western U.S. and Alaskan national parks—Spatial distribution and health thresholds. J. Am. Water Resour. Assoc. 2014, 50, 309-323. [CrossRef]

30. Vives, I.; Grimalt, J.O.; Catalan, J.; Rosseland, B.O.; Battarbee, R.W. Influence of altitude and age in the accumulation of arganochlorine compounds in fish from high mountain lakes. Environ. Sci. Technol. 2004, 38, 690-698. [CrossRef] [PubMed]

31. Vives, I.; Grimalt, J.O.; Venture, M.; Catalan, J.; Rosseland, B.O. Age dependence of the accumulation of organochlorine pollutants in brown trout (Salmo trutta) from a remote high mountain lake (Redo, Pyrenees). Environ. Pollut. 2005, 133, 343-350. [CrossRef]

32. Demers, M.J.; Kelly, E.N.; Blais, J.M.; Pick, F.R.; St Louis, V.L.; Schindler, D.W. Organochlorine Compounds in Trout from Lakes over a 1600 Meter Elevation Gradient in the Canadian Rocky Mountains. Environ. Sci. Technol. 2007, 41, 2723-2729. [CrossRef] [PubMed]

33. Schmid, P.; Kohler, M.; Gujer, E.; Zennegg, M.; Lanfranchi, M. Persistent organic pollutants, brominated flame retardants and synthetic musks in fish from remote alpine lakes in Switzerland. Chemosphere 2007, 67, 16-21. [CrossRef]

34. Yang, R.; Wang, Y.; Li, A.; Zhang, Q.; Jing, C.; Wang, T.; Wang, P.; Li, Y.; Jiang, G. Organochlorine pesticides and PCBs infish from lakes of the Tibetan plateau and the implications. Environ. Pollut. 2010, 158, 2310-2316. [CrossRef] [PubMed]

35. Hung, H.; Katsoyiannis, A.A.; Brorström-Lundén, E.; Olafsdottir, K.; Aas, W.; Breivik, K.; Bohlin-Nizzetto, P.; Sigurdsson, A.; Hakola, H.; Bossi, R.; et al. Temporal trends of Persistent Organic Pollutants (POPs) in arctic air: 20 years of monitoring under the Arctic Monitoring and Assessment Programme (AMAP). Environ. Pollut. 2016, 217, 52-61. [CrossRef] [PubMed]

36. Anttila, P.; Brorström-Lundén, E.; Hansson, K.; Hakola, H.; Vestenius, M. Assessment of the spatial and temporal distribution of persistent organic pollutants (POPs) in the Nordic atmosphere Author links open overlay panel. Atmos. Environ. 2016, 140, 22-23. [CrossRef]

37. Bossi, R.; Vorkamp, K.; Skov, H. Concentrations of organochlorine pesticides, polybrominated diphenyl ethers and perfluorinated compounds in the atmosphere of North Greenland. Environ. Pollut. 2016, 217, 4-10. [CrossRef]

38. Hu, D.; Hornbuckle, K.C. Inadvertent polychlorinated biphenyls in commercial paint pigments. Environ. Sci. Technol. 2010, 44, 2822-2827. [CrossRef]

39. Lohmann, R.; Northcott, G.; Jones, K. Assessing the contribution of diffuse domestic burning as a source of PCDD/Fs, PCBs, and PAHs to the UK atmosphere. Environ. Sci. Technol. 2000, 34, 2892-2899. [CrossRef]

40. Ikonomou, M.; Sather, P.; Oh, J.; Choi, W.; Chang, Y. PCB levels and congener patterns from Korean municipal waste incinerator stack emissions. Chemosphere 2002, 49, 205-216. [CrossRef]

41. Vijgen, L.; Weber, R.; Lichtensteiger, W.; Schlumpf, M. The legacy of pesticides and POPs stockpiles-A threat to health and the environment. Environ. Sci. Pollut. Res. Int. 2018, 32, 31793-31798. [CrossRef]

42. Fernández, P.; Grimalt, J.O. On the global distribution of persistent organic pollutants. Environ. Chem. 2003, 57, 514-521. [CrossRef]

43. Ma, Y.; Adelman, D.A.; Bauerfeind, E.; Cabrerizo, A.; Carrie, A.; McDonough, C.A.; Derek Muir, D.; Soltwedel, T.; Sun, C.; Wagner, C.C.; et al. Concentrations and Water Mass Transport of Legacy POPs in the Arctic Ocean. Geophys. Res. Lett. 2018, 45, 12972-12981. [CrossRef]

44. Rusenek, O.T. (Ed.) Baicalogy; Nauka: Novosibirsk, Russia, 2012; 466p, Available online: https://search.rsl.ru/ru/record/010067 19741 (accessed on 23 January 2022). (In Russian)

45. Domysheva, V.M.; Sorokovikova, L.M.; Sinyukovich, V.N.; Onishchuk, N.A.; Sakirko, M.V.; Tomberg, I.V.; Zhuchenko, N.A.; Golobokova, L.P.; Khodzher, T.V. Ionic Composition of Water in Lake Baikal, Its Tributaries, and the Angara River Source during the Modern Period. Russ. Meteorol. Hydrol. 2019, 44, 687-694. [CrossRef]

46. Yoshioka, N.; Ueda, S.; Khodzher, T.; Bashenkaeva, N.; Korovyakova, I.; Sorokovikova, L.; Gorbunova, L. Distribution of dissolved organic carbon in Lake Baikal and its watershed. Limnology 2002, 3, 159-168. [CrossRef]

47. Gorshkov, A.G.; Kustova, O.V.; Izosimova, O.N.; Babenko, T.A. POPs Monitoring System in Lake Baikal-Impact of Time or the First Need? Limnol. Freshwater Biol. 2018, 1, 43-48. [CrossRef]

48. Bobovnikova, T.I.; Virchenko, U.P.; Dibtsova, F.V.; Yablokov, A.V.; Solntseva, G.N.; Pastukhov, D.V. Aquatic mammals-Indicators of the presence of organochlorine pesticides and polychlorinated biphenyls in the aquatic environment. J. Hydrobiol. 1986, 22, 63-68. (In Russian)

49. Kucklik, J.R.; Bidleman, T.F.; McConnell, L.L.; Walla, M.D.; Ivanov, G.P. Organochlorines in the water and biota of Lake Baikal, Siberia. Environ. Sci. Technol. 1994, 28, 31-37. [CrossRef]

50. Kucklik, J.R.; Harvey, H.R.; Ostrom, P.H.; Ostrom, H.E.; Baker, J.E. Organochlorine dynamics in the pelagic food web of Lake Baikal. Environ. Toxicol. Chem. 1996, 15, 1388-1400. [CrossRef]

51. Iwata, H.; Tanabe, S.; Ueda, K.; Tatsukawa, R. Persistent Orgnochlorine Residues in Air, Water, Sediments, and Soils from the Lake Baikal Region, Russia. Environ. Sci. Technol. 1995, 29, 792-801. [CrossRef]

52. Gorshkov, A.G.; Kustova, O.V.; Dzyuba, E.V.; Zakharova, Y.R.; Shishlyannikov, S.M.; Khutoryanskiy, V.A. Polychlorinated biphenyls in Lake Baikal ecosystem. Chem. Sustain. Dev. 2017, 25, 269-278. [CrossRef] 
53. Kustova, O.V.; Stepanov, A.S.; Gorshkov, A.G. Determining the Indicator Congeners of Polychlorinated Biphenyls in Water at Ultratrace Concentration Level Using Gas Chromatography-Tandem Mass-Spectrometry. J. Anal. Chem. 2021, 76, $1028-1037$. [CrossRef]

54. FR.1.31.2021.40284. Method for Measuring the Mass Fractions of Polychlorinated Biphenyl Congeners in Fish (omul) Samples from Lake Baikal by Chromatography-Mass Spectrometry with Detection in the Monitoring Mode of Specified Reactions. Certificate No. 222.0156/RA.RU.311866/2021. Available online: https://docs.cntd.ru/document/437249035 (accessed on 23 January 2022).

55. Pravdin, I.F. Guide to the Study of Fish (Mainly Freshwater); Food Industry: Moscow, Russia, 1966; 376p, Available online: https:/ / search.rsl.ru/ru/record/01006163511 (accessed on 23 January 2022). (In Russian)

56. Chugunova, N.I. Guidelines for the Study of the Age and Growth of Fish; RAS: Moscow, Russia, 1959; 168p, Available online: http:/ / kpabg.ru/sites/default/ files/chugunova1957.pdf (accessed on 23 January 2022). (In Russian)

57. Van den Berg, M.; Birnbaum, L.S.; Denison, M.; De Vito, M.; Farland, W.; Feeley, M.; Fiedler, H.; Hakansson, H.; Hanberg, A.; Haws, L.; et al. The 2005 World Health Organization Reevaluation of Human and Mammalian Toxic Equivalency Factors for Dioxins and Dioxin-Like Compounds. Toxicol. Sci. 2006, 93, 223-241. [CrossRef] [PubMed]

58. Grzymala-Busse, J.W.; Goodwin, L.K.; Grzymala-Busse, W.J.; Zheng, X. Handling missing attribute values in preterm birth data sets. In International Workshop on Rough Sets, Fuzzy Sets, Data Mining, and Granular-Soft Computing, Regina, SK, Canada, 31 August-3 September 2005; Springer: Berlin/Heidelberg, Germany, 2005; pp. 342-351. Available online: https://sci2s.ugr.es/keel/pdf/ specific/congreso/grzymala_busse_goodwin05.pdf (accessed on 23 January 2022).

59. Oksanen, J.; Blanchet, G.F.; Friendly, M.; Kindt, R.; Legendre, P.; McGlinn, D.; Minchin, P.R.; O’Hara, R.B.; Simpson, G.L.; Solymos, P.; et al. Vegan: Community Ecology Package. R Package Version 2.5-6. 2019. Available online: https://CRAN.R-project.org/ package= vegan (accessed on 24 June 2020).

60. Benjamini, Y.; Hochberg, Y. Controlling the false discovery rate: A practical and powerful approach to multiple testing. J. R. Statist. Soc. B 1995, 57, 289-300. [CrossRef]

61. Kassambara, A.; Mundt, F. Factoextra: Extract and Visualize the Results of Multivariate Data Analyses, R Package Version; R Project for Statistical Computing: Vienna, Austria, 2017.

62. Warnes, G.R.; Bolker, B.; Bonebakker, L.; Gentleman, R.; Liaw, W.H.A.; Lumley, T.; Maechler, M.; Magnusson, A.; Moeller, S.; Schwartz, M.; et al. Package "gplots": Various R Programming Tools for Plotting Data, R Package Version 2.17.0; Science Open: Berlin, Germany, 2015. Available online: https://cran.r-project.org/web/packages/gplots/index.html(accessed on 24 June 2020).

63. Mantel, N. The detection of disease clustering and a generalized regression approach. Cancer Res. 1967, 27, 209-220. [PubMed]

64. Legendre, P.; Legendre, L. Numerical Ecology; Elsevier: Amsterdam, The Netherlands, 2012; 990p.

65. Megson, D.; Benoit, N.B.; Sandau, C.D.; Chaudhuri, S.R.; Long, T.; Coulthard, E.; Johnson, G.W. Evaluation of the effectiveness of different indicator PCBs to estimating total PCB concentrations in environmental investigations. Chemosphere 2019, $237,124429$. [CrossRef] [PubMed]

66. Smirnov, V.V.; Smirnova-Zalumi, L.V.; Sukhanova, L.V. Microevolution of the Baikal Omul Corogonus Autumnalis Migratorius (Georgi); SB RAS: Novosibirsk, Russia, 2009; 246p. (In Russian)

67. IARC. Polychlorinated Biphenyls and Polybrominated Biphenyls; Monographs on the Evaluation of Carcinogenic Risks to Humans; IARC: Lyon, France, 2015; Volume 107.

68. Fox, K.; Zauke, G.P.; Butte, W. Kinetics of Bioconcentration and Clearance of 28 Polychlorinated Biphenyl Congeners in Zebrafish (Brachydanio rerio). Ecotoxicol. Environ. Safety. 1994, 28, 99-109. [CrossRef]

69. Gobas, F.A.P.C.; Opperhuizen, A.; Hutzinger, O. Bioconcentration of hydrophobic chemicals in fish: Relationship with membrane permeation. Environ. Toxicol. Chem. 1986, 5, 637-646. [CrossRef]

70. Gobas, F.A.P.C.; Zhang, X.; Wells, R. Environ. Gastrointestinal magnification: The mechanism of biomagnification and food chain accumulation of organic chemicals. Environ. Sci. Technol. 1993, 27, 2855-2863. [CrossRef]

71. INERIS. Données Technico-Economiques sur les Substances Chimiques en France: Les polyChloroBiphenyles (PCB). DRC-11118962-11081A. 2011; p. 89. Available online: http:/ / www.ineris.fr/substances/fr (accessed on 18 June 2016).

72. State Committee of the Russian Federation for Environmental Protection. 1999. Order of 13 April, No 165. Available online: http:/ / www.dioxin.ru/doc/prikaz165.htm (accessed on 23 March 2020). (In Russian)

73. US EPA 440.5-88.006. 1998. Water Quality Standards Criteria Summaries: A Compilation of State/Federation Criteria. Available online: http:/ / www.epa.gov/waterscience/criteria/wqcriteria.html (accessed on 23 March 2020).

74. Vecchiato, M.; Zambon, S.; Argiriadis, E.; Barbante, C.; Gambaro, A.; Piazza, R. Polychlorinated biphenyls (PCBs) and polybrominated diphenyl ethers (PBDEs) in Antarctic ice-free areas: Influence of local sources on lakes and soils. Microchem. J. 2015, 120, 26-33. [CrossRef]

75. Fernandez, P.; Carrera, G.; Grimalt, J.O. Persistent organic pollutants in remote freshwater ecosystems. Aquat. Sci. 2005, 67, 263-273. [CrossRef]

76. Guzzella, L.; Poma, G.; De Paolis, A.; Roscioli, C.; Viviano, G. Organic persistent toxic substances in soils, waters and sediments along an altitudinal gradient at Mt. Sagarmatha, Himalayas, Nepal. Environ. Pollut. 2011, 159, 2552-2564. [CrossRef]

77. Villa, S.; Bizzotto, E.C.; Vighi, M. Persistent organic pollutant in a fish community on a sub-alpine lake. Environ. Pollut. 2011, 159, 932-939. [CrossRef]

78. ESIM. Unified State System of Information on the Situation in the World Ocean ЕСИМ. 2004. Available online: http:/ / esimo. oceanography.ru/esp2/index/index/esp_id/2/section_id/8/menu_id/4218 (accessed on 24 December 2021). (In Russian) 
79. Dai, G.; Liu, X.; Liang, G.; Han, X.; Shi, L.; Cheng, D.; Gong, W. Distribution of organochlorine pesticides (OCPs) and polychlorinated biphenyls (PCBs) in surface water and sediments from Baiyangdian Lake in North China. J. Environ. Sci. 2011, 23, 1640-1649. [CrossRef]

80. Piskorska-Pliszczynska, J.; Maszewski, S.; Warenik-Bany, M.; Mikolajczyk, S.; Goraj, L. Survey of persistent organochlorine contaminants PCDD, PCDF, and PCB in fish collected from the Polish Baltic fishing areas. Sci. World J. 2012, $2012,973292$. [CrossRef]

81. Eurofins. Dioxins and PCBs in Food Products: Maximum Levels and Action Levels; Eurofins: Nantes, France, 2019. 